\title{
Anti-infectious activity in plants of the genus Tabebuia
}

\author{
Francisco Javier Jiménez-González ${ }^{1}$, Luz Angela Veloza ${ }^{1}$, Juan Carlos Sepúlveda-Arias ${ }^{2 \bowtie}$
}

\begin{abstract}
Infectious diseases are a worldwide public health problem. There is growing research in the field of new plant-based drugs for treating such diseases. Our objective was to perform a systematic literature review to evaluate the anti-infectious activity (antibacterial, antifungal, antiviral and antiparasitic) attributed to plants of the Tabebuia (Bignoniaceae) genus. We conducted a search for the period of 2000-2013 in ScienceDirect, Scopus, PubMed, Embase, Napralert and SciELO databases using the following MeSH terms: Tabebuia, biological activity, bioactive compounds, chemical compounds, diseases, traditional medicine, tropical infections, infections and treatment. We found ethnobotanical and experimental (in vitro) evidence supporting the use of Tabebuia species for treating infectious diseases. In addition, the compounds responsible for their antimicrobial activity have been isolated, and their structures have been elucidated, emphasizing among them naphthoquinones such as lapachol. Natural products isolated from Tabebuia plants may be an alternative for developing new anti-infectious agents.
\end{abstract}

Keywords: Anti-infective agents, Bignoniaceae, Tabebuia, Naphthoquinones, Lapachol.

Edited by Gonzalo Sequeda四 \& Alberto Acosta

1 Grupo Polifenoles. Facultad de Tecnología, Universidad Tecnológica de Pereira, Pereira, Colombia.

2 Grupo Infección e Inmunidad. Facultad de Ciencias de la Salud. Universidad Tecnológica de Pereira. Pereira, Colombia.

Received: 20-06-2013 Accepted: 22-09-2013

Published on line: 18-10-2013

Citation: Jiménez-González FJ, Veloza LA, Sepúlveda-Arias JC (2013) Anti-infectious activity in plants of the genus Tabebuia. Universitas Scientiarum 18(3): 257-267 doi: 10.11144/Javeriana. SC18-3.aapg

Funding: Vicerrectoría de Investigaciones, Innovación y Extensión, Universidad Tecnológica de Pereira; Red de Universidades Públicas del Eje Cafetero, Alma Mater; COLCIENCIAS.

Electronic supplementary material: N/A

SICI: 2027-1352(201309/12)18:3<257:AAIPOTGT>2.0.TS;2-D

\section{Introduction}

Plants producelarge amounts of compounds known as phytochemicals, and each plant synthesizes a vast variety of these phytochemicals. Phytochemicals not only maintain the plant's physiological activities, but they also protect it against foreign agents such as bacteria, fungi, insects and animals that feed on them (Dixon 2001, Schultz 2002). Since ancient times, phytochemicals have been used as treatments to cure various diseases.

Presently, multiple pharmaceutical agents contain natural compounds, including drugs that contain variations of these natural molecules (Kinghorn 2001). Many plants have been used as 
the base or as precursors for developing several synthetic or semi-synthetic drugs (Wessjohann 2000, Newman et al. 2003). In fact, studies by Newman clearly demonstrate that $61 \%$ of all new small-molecule drugs introduced during 19812002 have been produced using natural products (7\% natural products, $27 \%$ natural-product derivatives, $5 \%$ synthetic derivatives from natural products and $23 \%$ synthetic compounds designed from a natural product). Natural products are an innovative source of therapeutic agents for treating infectious diseases, and other ailments (Altmann 2001).

The decreased susceptibility of infectious agents to antimicrobials has warranted the need to increase the therapeutic arsenal of anti-infectious agents, emphasizing antibacterial, antiparasitic and antifungal agents (Gould 2008, Pitman et al. 2011, Wise 2011). The scientific community and pharmaceutical companies have given medicinal plants special attention in the last years because of their promising potential to be used to develop innovative anti-infectious agents of natural origin (Osbourn 1996, Tagboto \& Townson 2001, Ginsburg \& Deharo 2011).

The Tabebuia genus includes approximately 100 species and is the largest genus in the Bignoniaceae family. This plant family is distributed from the southwestern United States to the northern regions of Argentina and Chile (Dvorkin-Camiel \& Whelan 2008), where almost one-half of its genus and species are located (Olmstead et al. 2009).

Species of the Tabebuia genus have been used empirically as anti-inflammatory, anti-cancer and anti-microbial agents in rural areas of Colombia, Bolivia, Brazil and other Latin-American countries (Bueno et al. 2001, Agra et al. 2007, Negrelle \& Fornazzari 2007, Gomez-Estrada et al. 2011, Hajdu \& Hohmann 2012); the Tabebuia genus is commonly recognized as a therapeutic alternative by rural or remote populations. The results of ethnobotanical and ethnopharmacological studies indicating the potential use of these plants to treat a large variety of diseases has encouraged the search of new phytotherapeutic drugs using plant biodiversity (Ospina et al. 2011).
The extensive use of Tabebuia species for the treatment of infectious diseases in traditional medicine in Latin America, and the lack of reviews in the field motivated this systematic review of literature summarizing the relevant information published in the last 13 years. To our knowledge, this is the first literature review concerning the anti-infectious activities of plants of the genus Tabebuia. Several Tabebuia species have been used in traditional medicine to treat infectious diseases; Lapachol, for example, (which was first isolated from Tabebuia avellanedae) has antibacterial, antiviral, antiparasitic and antifungal activities (like other napthoquinones). However, it is necessary to clearly identify compounds other than lapachol that have anti-infectious activity and the mechanisms of action responsible for these activities.

\section{Materials and Methods}

We performed a systematic review in the databases of Index Medicus/MEDLINE (www.pubmed. com), Scopus (www.scopus.com), ScienceDirect (www.sciencedirect.com), Embase (www.embase. com), Napralert (www.napralert.com) and SciELO (www.scielo.org) using the following combination of $\mathrm{MeSH}$ (Medical Subject Headings) terms: "Tabebuia" OR "biological activity" OR "bioactive compounds" OR "chemical compounds" OR "diseases" OR "traditional medicine" OR "tropical infections" OR "infections" AND "treatment". To uncover the prominence of Tabebuia plants in the development of new anti-infectious agents, we included all articles published in English, Spanish or Portuguese during the years 2000-2013. Completed the search, we identified 264 articles and selected 36 based on their titles, abstracts and review of the full text. The selected articles were grouped according to the associated biological (i.e., antibacterial, antifungal, antiviral and antiparasitic) activity; we also considered all complementary general references related to the review. Because the objective of this review was to show a general context of the ethnopharmacology of the genus Tabebuia and the compounds related with the antiinfectious activity, we excluded investigations related to phytochemical, chemical and genetic studies. 


\section{Discussion}

Antibacterial activity: The most extensive studies conducted have been on the antibacterial activity of extracts obtained from Tabebuia plants; this includes ethnobotanical and ethnopharmacological studies (Negrelle \& Fornazzari 2007, Gomez-Estrada et al. 2011). The ethyl acetate extract obtained from the inner bark of Tabebuia ocbracea and Tabebuia rosea inhibits Staphylococcus aureus growth at concentrations ranging between 1.25 and $10 \mathrm{mg} /$ well. This characteristic may be attributed to the presence of quinone-type compounds that have displayed activity against Staphylococcus aureus strains (Riffel et al. 2002). However, no inhibitory activity was found against Escherichia coli and Pseudomonas aeruginosa by Tabebuia ochracea and Tabebuia rosea in the ethyl acetate extract (Franco Ospina et al. 2013).

The hexane extract of the Tabebuia avellanedae (synonym Tabebuia impetiginosa) heartwood and its fractions exhibited antibacterial activity against methicillin-resistant Staphylococcus aureus (MRSA) and methicillin-sensitive Staphylococcus aureus (MSSA). This inhibitory effect is mainly attributed to the naphthoquinones $\alpha$-lapachone (1) and $\alpha$-xiloidone (2) (Figure 1) at minimum inhibitory concentrations (MICs) of $62.5 \mathrm{mg} / \mathrm{L}$ and $125 \mathrm{mg} / \mathrm{L}$, respectively (Machado et al. 2003). The biological activity of Tabebuia avellanedae naphthoquinones and those stereoselectively synthesized were recently evaluated. It was found that the (-)-5-hydroxy-2-(1'-hydoxyethyl) naphtho[2,3-b]furan-4,9-dione (3) and its positional isomer (-)-8-hydroxy-2-(1'-hydoxyethyl) naphtho[2,3-b]furan-4,9-dione (4) had a strong activity against Staphylococcus aureus and Bacillus subtilis, with MICs varying between 0.78 and 6.25 $\mu \mathrm{g} / \mathrm{mL}(0.78$ and $6.25 \mathrm{mg} / \mathrm{L}$ ) (Yamashita et al. 2009); these naphthoquinones are found in the inner bark of Tabebuia avellanedae (Wagner et al. 1989). Other naphthoquinone derivatives obtained from the Tabebuia avellanedae-isolated lapachol (5),<smiles>CC1(C)CCC2=C(O1)C(=O)c1ccccc1C2=O</smiles>

(1)<smiles>CC(C)=CCC1=C(O)C(=O)c2ccccc2C1=O</smiles>

(5)<smiles>CC1(C)C=CC2=C(O1)C(=O)c1ccccc1C2=O</smiles>

(2)

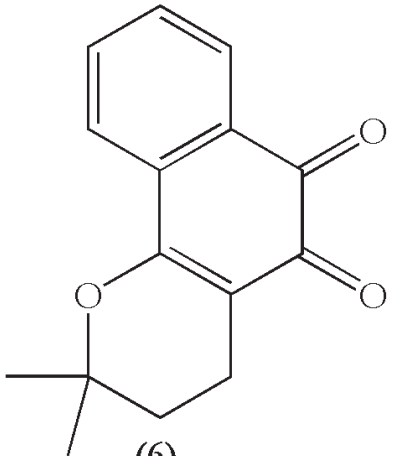

(6)<smiles>[R1]c1ccc([R2])c2c1C(=O)c1cc([C@H](C)O)oc1C2=O</smiles>

(3) $\mathrm{R}_{1}=\mathrm{OH} ; \mathrm{R}_{2}=\mathrm{H}$

(4) $\mathrm{R}_{1}=\mathrm{H} ; \mathrm{R}_{2}=\mathrm{OH}$<smiles>CC1(C)OC2c3ccccc3C(=O)C(=O)C2C1O</smiles>

(7)

Fig. 1. Chemical structure of naphthoquinone and naphthoquinone derivatives isolated from Tabebuia avellanedae. $\alpha$-lapachone (1), $\alpha$-xiloidone (2), (-)-5-hydroxy-2-(1'-hydoxyethyl)naphtho[2,3-b]furan-4,9-dione (3), (-)-8-hydroxy-2-(1'-hydoxyethyl)naphtho[2,3-b] furan-4,9-dione (4), lapachol (5), $\beta$-lapachone (6) ( \pm ) 3 hydroxy- $\beta$-N-lapachone (7). 
such as $\beta$-lapachone (6) and ( \pm ) 3-hydroxy- $\beta$-Nlapachone (7), displayed a considerable inhibitory activity against Staphylococcus aureus growth, with MICs of $8 \mu \mathrm{g} / \mathrm{mL}$ ( $8 \mathrm{mg} / \mathrm{L})$ for both compounds; however, no bactericidal activity was observed (Minimum Bactericidal Concentration, $\mathrm{MBC} \geq 512$ $\mu \mathrm{g} / \mathrm{mL}$ (512 mg/L) (Pereira et al. 2006). Lapachol, which is a biologically active naphthoquinone showed activity against several agents such as bacteria, fungus, viruses and parasites and has therefore been used as a target for the synthesis of naphthoquinone derivatives with potent antimicrobial activity (Hussain et al. 2007).

The ethanol extracted from the leaf of Tabebuia rosea has also been evaluated; at concentrations between 50 and $300 \mathrm{mg} / \mathrm{mL}$ (50,000 and 30,0000 $\mathrm{mg} / \mathrm{L}$ ) it can inhibit the growth of Klebsiella pneumoniae (Sathiya \& Muthuchelian 2008). This antibacterial activity can be associated with the presence of various active principles or phytoconstituents such as phenolic compounds, quinoids and flavonoids present in the leaf ethanol extract of Tabebuia rosea (Joselin et al. 2013).

When comparing the activity of furanonaphthoquinones, isolated from the inner bark of Tabebuia impetiginosa, against Helicobacterpylori with that of drugs used to treat infections caused by this bacteria such as amoxicillin, metronidazole and tetracycline, (Figure 2), three new compounds were identified: 2-(hydroxymethyl)anthraquinone (8) (MIC $2 \mu \mathrm{g} / \mathrm{mL} ; 2 \mathrm{mg} / \mathrm{L}$ ), anthraquinone-2carboxylic acid (9) (MIC $8 \mu \mathrm{g} / \mathrm{mL} ; 8 \mathrm{mg} / \mathrm{L})$ and lapachol (5) (MIC $4 \mu \mathrm{g} / \mathrm{mL} ; 4 \mathrm{mg} / \mathrm{L}$ ). These compounds displayed antibacterial activity against Helicobacter pylori, exhibiting higher effectiveness than metronidazole (MIC $32 \mu \mathrm{g} / \mathrm{mL} ; 32 \mathrm{mg} / \mathrm{L}$ ) but lower effectiveness than amoxicillin (MIC $0.063 \mu \mathrm{g} / \mathrm{mL} ; 0.063 \mathrm{mg} / \mathrm{L}$ ) and tetracycline (MIC $0.5 \mu \mathrm{g} / \mathrm{mL} ; 0.5 \mathrm{mg} / \mathrm{L}$ ) (Park et al. 2006). This activity has been previously reported by Nagata et al (1998). Not only do Tabebuia avellanedae innerbark compounds exert a direct effect on Helicobacter pylori but their ethanol extracts also have a direct protective effect on the gastric mucosa by inducing mucus production (Twardowschy et al. 2008).

The leaf methanolic extract from Tabebuia chrysantha inhibited the growth of Staphylococcus aureus at a concentration of $125 \mathrm{mg} / \mathrm{mL}(125,000$ $\mathrm{mg} / \mathrm{L})$. This extract was more active than the chloroform and ether extracts used at the same concentration (Pérez et al. 2007). These results suggest that the polar compounds found in the methanolic extract could be responsible for this activity; however, the antibacterial activity found was small. In addition, the authors found that none of the extracts obtained from Tabebuia chrysantha inhibited the growth of Escherichia coli, Proteus vulgaris and Pseudomona aeruginosa.

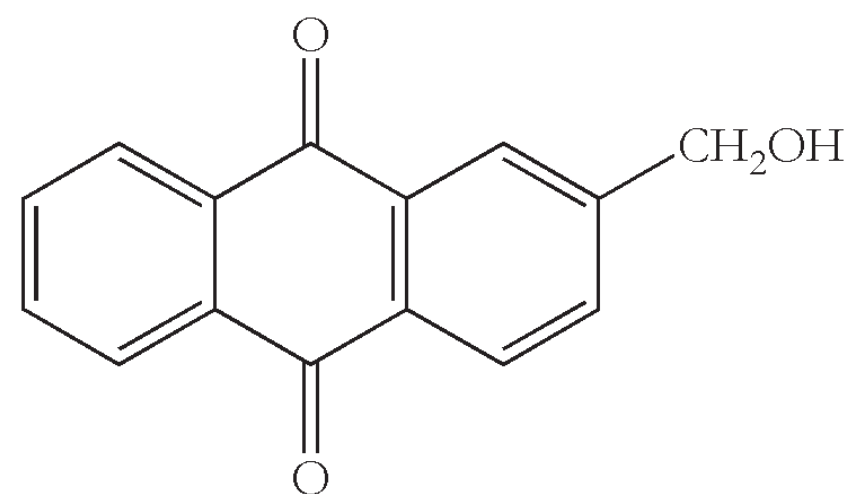

(8)

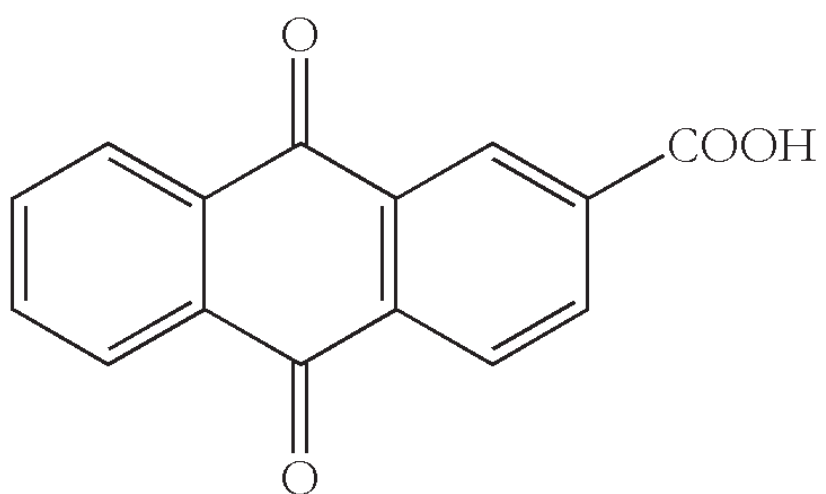

(9)

Fig. 2. Chemical structure of antraquinones isolated from Tabebuia impetiginosa inner bark. 2-(hydroxymethyl) anthraquinone (8), anthraquinone-2-carboxylic acid (9). 
In a more recent study, the antibacterial activity of 21 herbal extracts and four essential oils against Helicobacter pylori and Campylobacter jejuni was evaluated. Tabebuia impetiginosa hydro-alcoholic extract inhibited $36 \%$ of Helicobacter pylori growth but had no effect on Campylobacter jejuni (Cwikla et al. 2010), or on the adhesion of Campylobacter jejuni to human colon epithelial cells, demonstrated by $\mathrm{IC}_{50}$ values less than $3 \mathrm{mg} / \mathrm{mL}(3,000 \mathrm{mg} / \mathrm{L})$ (Bensch et al. 2011). The effect of Tabebuia impetiginosa inner-bark compounds on a group of human intestinal bacteria was also evaluated; anthraquinone-2-carboxylic acid efficiently inhibited Clostridium paraputrificum growth at a dose of $1 \mu \mathrm{g} /$ disc, while lapachol only moderately inhibited bacterial growth. Both compounds slightly inhibit the growth of Clostridium perfringes and Escherichia coli at a dose of $100 \mu \mathrm{g} /$ disc (Park et al. 2005). These results suggest that Tabebuia impetiginosa compounds may be valuable in the development of new effective agents against the growth of damaging intestinal bacteria such as Clostridium spp.

For the period evaluated in this review, we found only one report related to the antimycobacterial activity of a medicinal drink prepared with the hydro-alcoholic extract from the bark of Tabebuia avellanedae, which inhibited the growth of Mycobacterium tuberculosis H37Rv (Oliveira et al. 2007).

Natural products have also been used to inhibit the development of periodontal disease, as an adjunct to conventional oral-hygiene methods. For this reason, the antibacterial activity of a hydroalcoholic extract formulation consisting of various plant species, including Tabebuia impetiginosa, was tested; this formulation inhibits the growth of Staphylococcus aureus and Bacillus subtilis, with a MIC of $312.5 \mu \mathrm{L} / \mathrm{mL}$ (Cordeiro et al. 2006).

Antifungal activity: Powerful antifungal drugs currently exist; however, the development of fungal resistance to these drugs, drug toxicity and limitations in the bioavailability have created a need for the development of new drugs to control evolving fungal infections. Natural products might be of great utility in this field.
Fourteen plants commonly used in Paraguayan traditional medicine, including Tabebuia avellanedae, have been evaluated; dichloromethane extract from the bark of Tabebuia avellanedae was found to exerts a broad antifungal action particularly against Aspergillus fumigatus, Candida albicans, Cryptococcus neoformans, Microsporum gypseum, Penicillium purpurogenum, Saccharomyces cerevisiae and Trichophyton mentagrophytes. These aqueous and methanolic extracts displayed great inhibitory activity against Cryptococcus neoformans, Microsporum gypseum, Penicillium purpurogenum and Trichophyton mentagrophytes (Portillo et al. 2001).

A study of 11 plant species traditionally used in the Cerrado region of Brazil revealed that only four extracts, including the ethanol extract from Tabebuia caraiba, inhibited the growth of Candida albicans at a dose of $20 \mathrm{mg} / \mathrm{mL}(20,000 \mathrm{mg} / \mathrm{L})$. Tabebuia caraiba hexane and dichloromethane extracts inhibited the growth of Trichophyton rubrum. This inhibition was also determined from clinical isolates of the fungus, with MIC mean geometric values within the range of 170.39 to $23.23 \mu \mathrm{g} / \mathrm{mL}$ (170.39 to $23.23 \mathrm{mg} / \mathrm{L}$ ) (Melo e Silva et al. 2009).

In a research center in Campinas, Brazil, six plants were selected for evaluation of their potential activity against ten Candida species. The results revealed that the methanol extract from Tabebuia avellanedae exerts an inhibitory activity against $C$ andida albicans, Candida dubliniensis, Candida parapsilosis, Candida tropicalis, Candida guilliermondii, Candida utilis, Candida krusei, Candida lusitaniae, Candida glabrata and Candida rugosa, with MIC values in the range of 0.06 to $0.0001 \mathrm{mg} / \mathrm{mL}$ (60 to $0.1 \mathrm{mg} / \mathrm{L}$ ). The dichloromethane extract has inhibitory activity only against Candida krusei, with an MIC value of 0.06 $\mathrm{mg} / \mathrm{mL}$ (60 mg/L) (Hofling et al. 2010).

Furthermore, naphthoquinones (-)-5-hydroxy2-(1'-hydroxyethyl)naphtho[2,3-b] furan-4,9-dione and their positional isomer (-)-8-hydroxy-2-(1'hydroxyethyl)naphtho[2,3-b] furan-4,9-dione (stereoselectively synthesized) exhibited a moderate antifungal activity against $C$ andida albicans, Cryptococcus albidus and Aspergillus fumigatus, with MIC values of 25, 1.56 and $12.5 \mu \mathrm{g} / \mathrm{mL}(25,1.56$ and $12.5 \mathrm{mg} / \mathrm{L})$, respectively (Yamashita et al. 2009). 
Antiviral activity: We found only two studies evaluating the antiviral activity of extracts from Bignoniaceae species despite the urgency to develop new antiviral agents to combat the resistance and toxicity issues encountered when using existing antiviral drugs.

The results revealed no activity of Tabebuia aurea stem ethanol extracts and Tabebuia cassinoides stem and leaf ethanol extracts against encephalomyocarditis virus (EMCV), human herpes virus 1 (HHV-1) and vaccinia virus (Western Reserve strain, [VACV-WR]). This lack of activity was most likely caused by the high cytotoxicity of naphthoquinones present in the extracts (Brandão et al. 2010a). A second study evaluated the antiviral activity of Tabebuia impetiginosa, Tabebuia serratifolia and Tabebuia stenocalyx stem ethanol extracts and Tabebuia stenocaly leaf ethanol extract against EMCV, HHV-1 and VACV-WR viruses. The results demonstrated that only the Tabebuia impetiginosa extract exerted activity against HHV-1, with a one-half maximal effective concentration (EC50) of $166.6 \mu \mathrm{g} / \mathrm{mL}$ (Brandão et al. 2010b).

Antiparasitic activity: Despite the high prevalence of parasitic diseases in tropical and subtropical regions, their pharmacological treatment is difficult, especially the cases of neglected tropical diseases (NTDs) such as Leishmaniasis, Chagas disease and Malaria. The ineffectiveness of pharmacological treatments in the chronic phase of the majority of these pathologies, the drug's toxic effects, the presence of secondary effects and the parasitic resistance to these agents have stimulated interest in identifying new antiparasitic agents.

Lapachol, although structurally related to Atovaquone, exhibits low activity against Plasmodium berghei in mice and against Plasmodium falciparum in vitro. This fact has led to the synthesis of phenazines from lapachol, $\beta$-lapachone and their derivatives, thereby allowing the synthesis of compounds, such as 3-sulfonic acid-beta-lapachone-derived phenazine. The latter compound achieves 98\% inhibition of the Plasmodium berghei-induced parasitemia in mice (De Andrade-Neto et al. 2004). Tabebuia billbergii inner bark and wood extracts have been categorized based on their bioactivity; this has allowed the isolation and identification of several compounds. Naphthofurandiones, for example, display significant antimalarial activity in vitro against Plasmodium berghei (Gómez-Estrada et al. 2012); in particular, 2-acetyl-naphtho-[2,3b]-furan-4,9dione (10) (Figure 3), which had an $\mathrm{IC}_{50}$ of 0.002 $\mu \mathrm{M}$, surpassing chloroquine $\left(\mathrm{IC}_{50}: 0.110 \mu \mathrm{M}\right)$.

Several studies have revealed the trypanocidal activity of Tabebuia plant naphthoquinones, their heterocyclic derivatives (De Moura et al. 2001) and their $\beta$-lapachone naphthoimidazole derivative (Menna-Barreto et al. 2005). These two studies have tested the activity of 38 compounds against Trypanosoma cruzi and suggest that chemically

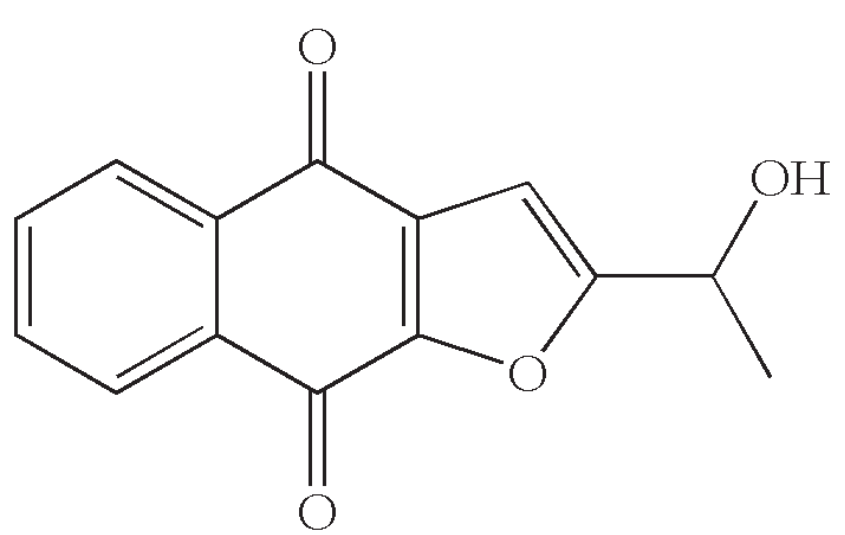

(11)

Fig. 3. Chemical structure of naphthofurandiones with antiparasitic activity. 2 -acetyl-4H,9H-naphtho[2,3-b]furan4,9-dione (10), 2-(1-hydroxyethyl)-4H,9H-naphtho[2,3-b]furano-4,9-dione (11). 
modifying the naphthoquinones, especially their imidazole ring, could produce compounds with high trypanocidal activity.

Hexane, chloroform and hydro-alcohol extracts obtained from the bark of Tabebuia serratifolia, a plant used in traditional Peruvian medicine for treating cutaneous leishmaniasis, were recently tested for their trypanocidal and anti-leishmanial activity (Gonzalez-Coloma et al. 2012).

The chloroform extract was the most effective against Trypanosoma cruzi and Leishmania infantum parasites, with inhibition percentages greater than $96 \%$ and extract concentrations between 400 and $800 \mu \mathrm{g} / \mathrm{mL}$ (400 and $800 \mathrm{mg} / \mathrm{L}$ ). A mixture of saturated alkanes, such as tricosane, tetracosane and pentacosane, among others, together with rotenone and naphthoquinones 2-acetyl-4H,9H-naphtho[2,3-b] furan-4,9-dione (10) and 2-(1-hydroxyethyl)-4H,9H-naphtho[2,3-b] furano-4,9-dione (11) (Figure 3), were isolated and identified from the hydro-alcoholic extract. Naphthoquinone (11) was the most active of these agents against Leishmania infantum and Trypanosoma cruzi, with a growth-inhibition $\left(\mathrm{GI}_{50}\right)$ concentration of $0.01 \mu \mathrm{g} / \mathrm{mL}(0.01 \mathrm{mg} / \mathrm{L})$. This value was lower than the Nifurtimox $\mathrm{GI}_{50}$ and similar to that of Amphotericin B. These naphthoquinones were previously isolated from Tabebuia cassinoides and Tabebuia ochracea (Zani et al. 1991). We present a summary of the results on anti-infectious activity the genus Tabebuia in Table 1.

Table 1. Tabebuia genus plants with anti-infectious activity.

\begin{tabular}{|c|c|c|c|c|}
\hline Plant & Part Used & Extract & Activity & Reference \\
\hline Tabebuia ochracea & Inner bark & Ethyl acetate & $\begin{array}{l}\text { Antibacterial, Antioxidant } \\
\text { and Anti-inflammatory }\end{array}$ & Franco Ospina et al. (2013) \\
\hline \multirow{2}{*}{ Tabebuia rosea } & Inner bark & Ethyl acetate & $\begin{array}{l}\text { Antibacterial, Antioxidant } \\
\text { and Anti-inflammatory }\end{array}$ & Franco Ospina et al. (2013) \\
\hline & Leaf & Ethanol & Antibacterial & Sathiya \& Muthuchelian (2008) \\
\hline \multirow{2}{*}{ Tabebuia avellanedae } & $\begin{array}{l}\text { Heartwood and } \\
\text { Inner bark }\end{array}$ & Hexane & $\begin{array}{l}\text { Antibacterial, Antiproliferative, } \\
\text { Antitumor, Antifungal and } \\
\text { Antimicrobial }\end{array}$ & $\begin{array}{l}\text { Machado et al. (2003) } \\
\text { Yamashita et al. (2009) }\end{array}$ \\
\hline & Bark & $\begin{array}{l}\text { Dichloromethane, } \\
\text { Aqueous and } \\
\text { Methanol }\end{array}$ & Antifungal & $\begin{array}{l}\text { Portillo et al. (2001) } \\
\text { Hofling et al. (2010) }\end{array}$ \\
\hline \multirow{3}{*}{ Tabebuia impetiginosa } & Inner bark & Methanol & Antimicrobial & Park et al. (2006) \\
\hline & Bark & Hydroalcohol & $\begin{array}{l}\text { Antibacterial and } \\
\text { anti-mycobacterial }\end{array}$ & $\begin{array}{l}\text { Cwikla et al. (2010) } \\
\text { Oliveira et al. (2007) } \\
\text { Cordeiro et al. (2006) }\end{array}$ \\
\hline & Stem & Ethanol & Antiviral & Brandão et al. (2010b) \\
\hline Tabebuia caraiba & $\begin{array}{l}\text { Stem bark, } \\
\text { stem wood }\end{array}$ & $\begin{array}{l}\text { Ethanol, hexane, } \\
\text { dichloromethane }\end{array}$ & Antifungal & Melo e Silva et al. (2009) \\
\hline Tabebuia billbergii & $\begin{array}{l}\text { Inner bark; } \\
\text { wood }\end{array}$ & Dichloromethane & Antimalarial & Gómez-Estrada et al. (2012) \\
\hline Tabebuia serratifolia & Bark & Hydroalcoholic & Antiparasitic & González-Coloma et al. (2012) \\
\hline
\end{tabular}




\section{Conclusion}

The resistance of several microorganisms to antimicrobial treatment has increased in the last years; natural products may potentially be a source to produce new drugs to treat infectious diseases. Various Tabebuia species have been used in traditional medicine to treat bacterial, fungal, viral and parasitic diseases, and other ailments. Tabebuia avellanedae, also known as Tabebuia impetiginosa, is the species that has been most extensively studied. In these studies, various compounds exhibiting biological activities have been isolated, naphthoquinones such as lapachol and $\beta$-lapachone being the most significant. Compounds isolated from different Tabebuia species have been characterized and utilized to synthesize derivatives. These derivatives can potentially be used as a source for new antimicrobial agents; however, it is essential we evaluate their mechanisms of action. Because the experimental methods employed in the evaluated literature differ significantly, it is impossible to conduct a side-by-side comparison of the results reported for each group of microorganisms. By understanding the traditional use of these plants, and conducting phytochemical research and investigations of their biological activities (in vivo and in vitro), we will attain the knowledge necessary for future discovery of new compounds for the control of infectious diseases.

\section{Acknowledgements}

The authors gratefully acknowledge financial support from Vicerrectoría de Investigaciones, Innovación y Extensión, Universidad Tecnológica de Pereira (Projects 9-12-3 and E9-11-10), Red de Universidades Públicas del Eje Cafetero, Alma Mater (Project AMFRI07-10 ) and Departamento Administrativo de Ciencia, Tecnología e Innovación, COLCIENCIAS (Doctoral Scholarship to FJJG).

\section{Conflict of interest}

The author(s) declare that they have no conflicts of interest.

\section{References}

Agra MF, Baracho GS, Nurit K, Basílio IJLD, Coelho VPM (2007) Medicinal and poisonous diversity of the flora of "Cariri Paraibano", Brazil. Journal of Ethnopharmacology 111(2):383-395 doi: 10.1016/j.jep.2006.12.007

Altmann KH (2001) Microtubule-stabilizing agents: a growing class of important anticancer drugs. Current Opinion in Chemical Biology 5(4):424-431 doi: 10.1016/S1367-5931(00)00225-8

Bensch K, Tiralongo J, Schmidt K, Matthias A, Bone KM, Lehmann R, Tiralongo E (2011) Investigations into the antiadhesive activity of herbal extracts against Campylobacter jejuni. Phytotherapy Research 25(8):1125-1132

doi: $10.1002 /$ ptr.3384

Brandão GC, Kroon EG, Dos Santos JR, Stehmann JR, Lombardi JA, Braga de Oliveira A (2010a) Antiviral activity of Bignoniaceae species occurring in the State of Minas Gerais (Brazil): part 1. Letters in Applied Microbiology 51(4):469-476 doi: 10.1111/j.1472-765X.2010.02924.x

Brandão GC, Kroon EG, dos Santos JR, Stehmann JR, Lombardi JA, de Oliveira AB (2010b) Antiviral activities of plants occurring in the state of Minas Gerais, Brazil. Part 2. Screening Bignoniaceae species. Brazilian Journal of Pharmacognosy 20(5):742-750 doi: 10.1590/S0102-695X2010005000035

Bueno JG, Isaza G, Gutierrrez F, Carmona WD, Pérez JE (2001) Estudio etnofarmacológico de plantas usadas empíricamente por posibles efectos inmunoestimulantes. Revista Médica de Risaralda 7:8-12

Cordeiro CHG, Do Sacramento LVS, Corrêa MA, Pizzolitto AC, Bauab TM (2006) Herbal extracts in an experimental mouthwash: Pharmacognostics analysis and antibacterial activity. Revista Brasileira de Ciencias Farmaceuticas 42(3):395-404

Cwikla C, Schmidt K, Matthias A, Bone KM, Lehmann $\mathrm{R}$, Tiralongo E (2010) Investigations into the antibacterial activities of phytotherapeutics against Helicobacter pylori and Campylobacter jejuni. Phytotherapy Research 24(5):649-656

De Andrade-Neto VF, Goulart MO, da Silva Filho JF, da Silva MJ, Pinto Mdo C, Pinto AV, Zalis MG, Carvalho LH, Krettli AU (2004) Antimalarial activity of phenazines from lapachol, beta-lapachone and its derivatives against Plasmodium falciparum in vitro and Plasmodium berghei in vivo. Bioorganic \& Medicinal Chemistry Letters 14(5):1145-1149 doi: 10.1016/j.bmcl.2003.12.069

De Moura KCG, Emery FS, Neves-Pinto C, Pinto MDCFR, Dantas AP, Salomão K, De Castro 
SL, Pinto AV (2001) Trypanocidal Activity of Isolated Naphthoquinones from Tabebuia and Some Heterocyclic Derivatives: A Review from an Interdisciplinary Study. Journal of the Brazilian Chemical Society 12(3):325-338

Dixon RA (2001) Natural products and plant disease resistance. Nature 411(6839):843-847

Dvorkin-Camiel L, Whelan JS (2008) Tropical american plants in the treatment of infectious diseases. Journal of Dietary Supplements 5(4):349-372 doi: 10.1080/19390210802519648

Franco Ospina LA, Castro Guerrero JP, Ocampo Buendía YC, Pájaro Bolívar IB, Díaz Castillo F (2013) Antiinflammatory, antioxidant and antibacterial activity of two species of Tabebuia genus. Revista Cubana de Plantas Medicinales 18(1):34-46

Ginsburg H, Deharo E (2011) A call for using natural compounds in the development of new antimalarial treatments - an introduction. Malaria Journal 10 Suppl 1:S1 doi: 10.1186/1475-2875-10-S1-S1

Gomez-Estrada H, Diaz-Castillo F, Franco-Ospina L, Mercado-Camargo J, Guzman-Ledezma J, Medina JD, Gaitan-Ibarra R (2011) Folk medicine in the northern coast of Colombia: an overview. Journal of Ethnobiology and Ethnomedicine 7:27

doi: 10.1186/1746-4269-7-27

Gómez-Estrada H, Gaitán-Ibarra R, Díaz-Castillo F, Pérez HA, Medina JD (2012) In vitro antimalarial activity of fractions and constituents isolated from Tabebuia billbergii. Revista Cubana de Plantas Medicinales 17(2):172-180

Gonzalez-Coloma A, Reina M, Saenz C, Lacret R, RuizMesia L, Aran VJ, Sanz J, Martinez-Diaz RA (2012) Antileishmanial, antitrypanosomal, and cytotoxic screening of ethnopharmacologically selected Peruvian plants. Parasitology Research 110(4):1381-1392 doi: 10.1007/s00436-011-2638-3

Gould IM (2008) The epidemiology of antibiotic resistance. International Journal of Antimicrobial Agents 32 Suppl 1:S2-9

doi: 10.1016/j.ijantimicag.2008.06.016

HajduZ, Hohmann J (2012) Anethnopharmacological survey of the traditional medicine utilized in the community of Porvenir, Bajo Paraguá Indian Reservation, Bolivia. Journal of Ethnopharmacology 139(3):838-857 doi: 10.1016/j.jep.2011.12.029

Hofling JF, Anibal PC, Obando-Pereda GA, Peixoto IA, Furletti VF, Foglio MA, Goncalves RB (2010) Antimicrobial potential of some plant extracts against Candida species. Brazilian Journal of Biology 70(4):1065-1068

doi: 10.1590/S1519-69842010000500022
Hussain H, Krohn K, Ahmad VU, Miana GA, Green IR (2007) Lapachol: an overview. ARKIVOC (II):145-171

Joselin J, Brintha TSS, Florence AR, Jeeva S (2013) Phytochemical evaluation of Bignoniaceae flowers. Journal of Chemical and Pharmacentical Research 5(4):106-111

Kinghorn AD (2001) Pharmacognosy in the 21st century*. Journal of Pharmacy and Pharmacology 53(2):135-148

doi: $10.1211 / 0022357011775334$

Machado TB, Pinto AV, Pinto MC, Leal IC, Silva MG, Amaral AC, Kuster RM, Netto-dosSantos KR (2003) In vitro activity of Brazilian medicinal plants, naturally occurring naphthoquinones and their analogues, against methicillin-resistant Staphylococcus aureus. International Journal of Antimicrobial Agents 21(3):279-284 doi: 10.1016/S0924-8579(02)00349-7

Melo e Silva F, de Paula JE, Espindola LS (2009) Evaluation of the antifungal potential of Brazilian Cerrado medicinal plants. Mycoses 52(6):511-517 doi: 10.1111/j.1439-0507.2008.01647.x

Menna-Barreto RF, Henriques-Pons A, Pinto AV, Morgado-Diaz JA, Soares MJ, De Castro SL (2005) Effect of a beta-lapachone-derived naphthoimidazole on Trypanosoma cruzi:identification of target organelles. Journal of Antimicrobial Chemotherapy 56(6):1034-1041 doi: $10.1093 / \mathrm{jac} / \mathrm{dki} 403$

Nagata K, Hirai KI, Koyama J, Wada Y, Tamura $\mathrm{T}$ (1998) Antimicrobial activity of novel furanonaphthoquinone analogs. Antimicrobial Agents and Chemotherapy 42(3):700-702

Negrelle RRB, Fornazzari KRC (2007) Ethnobotanical study in two rural communities (Limeira and Riberião Grande) in Guaratuba (Paraná, Brazil). Revista Brasileira de Plantas Medicinais 9(2):36-54

Newman DJ, Cragg GM, Snader KM (2003) Natural products as sources of new drugs over the period 1981-2002. Journal of Natural Products 66(7):1022-1037 doi: 10.1021/np0300961

Oliveira DG, Prince KA, Higuchi CT, Santos ACB, Lopes LMX, Simões MJS, Leite CQF (2007) Antimycobacterial activity of some Brazilian indigenous medicinal drinks. Revista de Ciencias Farmacenticas Básica e Aplicada 28(2):165-169

Olmstead RG, Zjhra ML, Lohmann LG, Grose SO, Eckert AJ (2009) A molecular phylogeny and classification of Bignoniaceae. American Journal of Botany 96(9):1731-1743

Osbourn AE (1996) Preformed Antimicrobial Compounds and Plant Defense against Fungal Attack. The Plant Cell 8(10):1821-1831

doi: $10.1105 /$ tpc.8.10.1821 
Ospina LF, Aragón DM, Vergel NE, Isaza G, Pérez JE (2011) Anti-inflammatory and antioxidant activities of Phenax rugosus (poir.) wedd and Tabebuia chrysanta G. Nicholson. Vitae 18(1):49-55

Park BS, Kim JR, Lee SE, Kim KS, Takeoka GR, Ahn YJ, Kim JH (2005) Selective growth-inhibiting effects of compounds identified in Tabebuia impetiginosa inner bark on human intestinal bacteria. Journal of Agricultural and Food Chemistry 53(4):1152-1157 doi: 10.1021/jf0486038

Park BS, Lee HK, Lee SE, Piao XL, Takeoka GR, Wong RY, Ahn YJ, Kim JH (2006) Antibacterial activity of Tabebuia impetiginosa Martius ex DC (Taheebo) against Helicobacter pylori. Journal of Ethnopharmacology 105(1-2):255-262

Pereira EM, Machado Tde B, Leal IC, Jesus DM, Damaso CR, Pinto AV, Giambiagi-deMarval M, Kuster RM, Santos KR (2006) Tabebuia avellanedae naphthoquinones: activity against methicillin-resistant Staphylococcalstrains, cytotoxic activity and in vivo dermal irritability analysis. Annals of Clinical Microbiology and Antimicrobials 5:5

doi: 10.1186/1476-0711-5-5

Pérez JE, Isaza G, Acosta SM (2007) Actividad antibacteriana de extractos de Phenax rugosus y Tabebuia chrysantha. Biosalud 6:59-68

Pitman SK, Drew RH, Perfect JR (2011) Addressing current medical needs in invasive fungal infection prevention and treatment with new antifungal agents, strategies and formulations. Expert Opinion on Emerging Drugs 16(3):559-586 doi: $10.1517 / 14728214.2011 .607811$

Portillo A, Vila R, Freixa B, Adzet T, Canigueral S (2001) Antifungal activity of Paraguayan plants used in traditional medicine. Journal of Ethnopharmacology 76(1):93-98

Riffel A, Medina LF, Stefani V, Santos RC, Bizani D, Brandelli A (2002) In vitro antimicrobial activity of a new series of 1,4-naphthoquinones. Brazilian Journal of Medical and Biological Research 35(7):811-818

Sathiya M, Muthuchelian K (2008) Studies on Phytochemical Profile and Antibacterial Activity of Ethanolic Leaf Extract of Tabebuia rosea (Bertol.) DC. Ethnobotanical Leaflets 12:1153-1157

Schultz JC (2002) Biochemical ecology: How plants fight dirty. Nature 416(6878):267-267

Tagboto S, Townson S (2001) Antiparasitic properties of medicinal plants and other naturally occurring products. Advances in Parasitology 50:199-295

Twardowschy A, Freitas CS, Baggio CH, Mayer B, dos Santos AC, Pizzolatti MG, Zacarias AA, dos Santos EP, Otuki MF, Marques MC (2008) Antiulcerogenic activity of bark extract of Tabebuia avellanedae, Lorentz ex Griseb. Journal of Ethnopharmacology 118(3):455-459 doi: $10.1016 /$ j.jep.2008.05.013

Wagner H, Kreher B, Lotter H, Hamburger MO, Cordell GA (1989) Structure Determination of New Isomeric Naphtho[2,3-b]furan-4,9-diones from Tabebuia avellanedae by the selective-INEPT technique. Helvetica Chimica Acta 72(4):659-667 doi: 10.1002/hlca.19890720406

Wessjohann LA (2000) Synthesis of natural-productbased compound libraries. Current Opinion in Chemical Biology 4(3):303-309

doi: 10.1016/S1367-5931(00)00093-4

Wise R (2011) The urgent need for new antibacterial agents. The Journal of antimicrobial chemotherapy 66(9):1939-1940 doi: $10.1093 / \mathrm{jac} / \mathrm{dkr} 261$

Yamashita M, Kaneko M, Tokuda H, Nishimura K, Kumeda Y, Iida A (2009) Synthesis and evaluation of bioactive naphthoquinones from the Brazilian medicinal plant, Tabebuia avellanedae. Bioorganic \& Medicinal Chemistry 17(17):6286-6291 doi: 10.1016/j.bmc.2009.07.039

Zani CL, De Oliveira AB, De Oliviera GG (1991) Furanonaphthoquinones from Tabebuia ochracea. Phytochemistry 30(7):2379-2381 doi: 10.1016/0031-9422(91)83653-3 


\section{Actividad anti-infecciosa en plantas del género Tabebuia}

Resumen. Dada la importancia de las enfermedades infecciosas como problema de salud pública a nivel mundial y la búsqueda de nuevos medicamentos basados en plantas para tratar dichas enfermedades; se realizó una revisión sistemática de literatura con el fin de evaluar la actividad anti-infecciosa (antibacteriana, antifúngica, antiviral y antiparasitaria) reportada en plantas pertenecientes al género Tabebuia (Bignoniaceae). Las bases de datos fueron: ScienceDirect, Scopus, Pubmed, Embase y Napralert, SciELO, durante 2000 - 2013. Se utilizaron términos en MeSH como: Tabebuia, biological activity, bioactive compounds, chemical compounds, diseases, traditional medicine, tropical infections, infections and treatment. Existe evidencia tanto etnobotánica como experimental (in vitro) que soporta el uso de especies del género Tabebuia en el tratamiento de enfermedades infecciosas. Adicionalmente, se encontró reportado y se esclareció estructuralmente los compuestos responsables de la actividad antimicrobiana, donde se destacan naftoquinonas como el lapachol. Se concluye a partir de la revisión que los productos naturales aislados de las plantas del género Tabebuia podrían considerarse alternativas para el desarrollo de nuevos agentes anti-infecciosos.

Palabras clave: Actividad anti-infecciosa, Bignoniaceae, Tabebuia, Naftoquinonas, Lapachol.

\section{Atividade anti-infecciosa em plantas do gênero Tabebuia}

Resumo. Dada a importância das doenças infecciosas como problema de saúde pública a nível mundial e a procura crescente de novos medicamentos baseados em plantas para tratar tais doenças, realiza se uma pesquisa sistematizada da literatura com o fim de avaliar a atividade anti-infecciosa (antibacteriana, antifúngica, antiviral y antiparasitária) reportada em plantas pertenecientes ao gênero Tabebuia (Bignoniaceae). Foi realizada uma pesquisa nas bases de dados ScienceDirect, Scopus, Pubmed, Embase y Napralert, assim como em SciELO, durante o período 2000 - 2013, empregando os términos MeSH: Tabebuia, biological activity, bioactive compounds, chemical compounds, diseases, traditional medicine, tropical infections, infections and treatment. Existe evidencia tanto etnobotánica como experimental (in vitro) que suporta o uso das espécies do gênero Tabebuia no tratamento das doenças infecciosas e adicionalmente, há sido isolado e identificado estruturalmente os compostos responsáveis da sua atividade antimicrobiana, donde se destacam as naftoquinonas como o lapachol. Os produtos naturais isolados de plantas do gênero Tabebuia poderiam considerar se como uma alternativa para o desarrolho de novos agentes anti-infecciosos.

Palavras-chave: Agentes anti-infecciosos, Bignoniaceae, Tabebuia, Naphthoquinones, Lapachol. 